\title{
Anti-corruption as a variable for civil servants' performance measurement: A systematic literature review
}

\author{
Rastiana Puspitarini ${ }^{1 *}$ \\ Central Java Province Government Indonesia
}

\section{ARTICLE INFORMATION ABSTRACT}

\section{Article history:}

Data submission : January 10, 2019

$1^{\text {st }}$ revision: March 16, 2019

Accepted: April 19, 2019

Available online: December 12, 2019

Keywords: Corruption; Performance measurement; Employees performance; Human resources; Good government.

\begin{abstract}
The purpose of this research is to elaborate variables of anti-corruption in the performance measurement in civil servants. This study was conducted by describe and analyze the experience of Great Britain to reduce corruption in the public sector. A systematic leitrature review was conducted to analyse anti-corruption varibales in the civil servant performance measurement. The findings show that two main variables used in the performance measurement: moral revolution and compliance. The finding suggests that the need for integrating moral revolution and compliance in order to optimize the combating of corruption in public sectors.
\end{abstract}

2019 FIA UB. All rights reserved.

\section{Introduction}

Corruption, problematical behavior affecting a detrimental effect in the society, is seriously fought by both national and international levels. International organizations publish particular ranks informing the international society the corruption level in the world in order to give competition environment effecting social and economic growth among the countries. For examples, World Economic Forum yearly publishes Global Competitiveness Report, Transparancy International with its annual Corruption Perceptions Index, Heritage Foundation collaborates with Wall Strees Journal continually publishes Index of Economic Freedom, and World Bank produces Country Policy and Institutional Assessment (Asian Development Bank, 2015).

Furthermore, showing serious action, several countries form particular institution which special authorization on combating corruption. Hongkong, since

\footnotetext{
* Corresponding author email: rastie99@ gmail.com Telp: +628119204790
}

1974, forms Independent Commision Againts Corruption supported by sufficient budget and professional human resource to against corruption. Corrupt Practices Investigation Bureau, Singapore's special institution combating corruption, exist because of inefficiency of Police performance reducing corruption (Pratama, 2019). Another example is Indonesia, which establishes Komisi Pemberantasan Korupsi since 2002, that institution, however, are not enough to stop the corruption especially its action involving civil servants.

Civil servants involving to corruption shows not a little number or probably massive in several countries. National Civil Service Agency of Indonesia in their press release (Badan Kepegawaian Negara, 2018) published that there were 2.674 civil servants sentenced guilty on corruption then being dissmished without honor. Along with politicsl parties and parliament, civil servants positioned in the top three the most corrupt in Philipina. At least $72 \%$ of surveyees stated that civil 
servant within Philipina extremely corrupt (Nawaz \& Bridi, 2008) and effected more than $30 \%$ of government projects budget lost due to the corruption.

The number of corrupting civil servants in particular countries does not mean they are not serious to fight corruption. Declared the laws of anti-corruption, formed anti-corruption institution, tighten budget system, and other actions are implemented by the countries attempting corruption reduction on public sectors that mostly are committed by civil servants. What instrument that is actually need by the countries to reduce corruption among the civil servants?

These days, performance measurement system of civil servants measure the working effectivity among civil servants. It mostly become a point to measure the incentive, known as remuneration, given to the civil servants and occasionally leads distortion to reach each civil servant target achievement (Paul). Hence, current remuneration system creates a new variety of corruption although it is designed to reduction the corruption.

Scholars define perfomance measurements in various definitions. However, in shortly meaning, performance measurement is a multi-dimensional set of performance measures for the planning and management of a business (Bourne et al., 2003). When fight against corruption is being a method to optimize the bussiness over the state, its performance should involve anticorruption.

This research is aimed to find the indicator/s within performance measurement of civil sercants through systematic literature review.

\section{Discussion}

As Transparancy International explains it, an organization that concerns to against corruption, corruption is the abuse of entrusted power to private gain and can be classified into gran, petty, and political depending on lost amount and sector where it occurs (Transparency International, 2018). Girling set up the type of corruption into two types; 1) social character of corruption, which involves capital-democracy interaction; and 2) individualistic character of corruption, which involve theoretical disregard for the interaction in economics and politics practices (Girling, 1997).

Detrimental effect caused by corruption urges the universe to formulate anti-corruption and creates a better condition to continue sustain development. Showing the seriousness combating corruption, the countries regulate anti-corruption into their internal regulation. Formulating anti-corruption into a regulation is not an easy way. However, the involvement of state' executive and legislative body possibly turn to be a restriction when the spirits are not reciprocal between them. Dispite of fulfilling the international commitment, formulating anti-corruption regulation minimizes the abuse of power then whether they want it or not, the regulation concerning anti-corruption is proceed and legally applied.

\subsection{Anti-corruption in Victorian Age (Great Britain)}

Victorian age brings a progressive movement in the public life in Britain. Noted from the fact, Britain had led world' economy, prime on industrial sector, and took advantageous from its unique in the Victorian age. It was caused by the insistence of middle-class society who wanted a reform in Britain. Although aristrocat governed, the middle-class of the society encourages the similarity between them and the aristrocat. The middleclass, however, aimed to erase the privilege and patronize of aristrocat which identically with jobbery: an unprofessional and incompetence civil servant (Girling, 1997).

The spirit of that change successfully achieved a great result. Civil servants in Britain did not impartial, expert, and incorrupt and they were even sent to abroad to work. This, explained by Jeremy Betham, was called "moral revolution" which emphasized on each personal integrity both in public and private behaviour of civil servant and resulted promotion by merit, professional efficiency, retrenchment, and economy, publicity, and full financial accountability.

Outlining the reform of public sector in Britain, starting point of moral evolution in Britain was the creation of gentlement ideal. Mathew Arnold believed that the primary action had to be in the school where able to pursue carier and profession of somebody. Then, they had group of networking and created constantly behavior, which formed gentlement. While in the school, the principles of discipline, obedience, respect, responsibility, and conciouness of imperial system were established and plated to each student of public school in order to push imperial ethos that unfortunately decline the economics. However, the existence of religion and Christian virtue adopted in political economy brought moral investation toward nation' ethical progress in Britain and linked to the attempt of corruption elimination, arbritary, inefficient vestige of the autocratic past.

Inspired by Bentham' writings, Utilitarian wanted new era which placed certainty into written law to obtain three goals; liberty and democracy and freeing economic development from 'harmful' state regulation 
or restraint of trade by associations, 3) legislation for much needed social reforms, especially in the antiquated and obscurantist legal system, in education, public health, factory conditions, tariff reform leading to free trade, local government and the democratic extension of the franchise (Girling, 1997). To reach effectiveness of the written law, a social reformer Edwin Chadwick argued that it supposed to be controlled by a central government agent with strengthen power.

However, the achievement of public improvement in Britain was not only caused by one side of the society. There was social concencus coming from upper, middle, and lower societies. Eventhough the great depression on social and politic attacked, the condition of civil service still persisted these decades (Girling, 1997).

Shortly, "moral revolution" and its innovation are the key of the public sector reformation in Britain. It was marked by ascendancy of the bourgeois ethic; the imposition of professional standards; and moral earnestness and regeneration. Supported by written law and social concencus among the societies, the condition of civil servant showed positive progress.

\subsection{Anti-corruption in private sector}

Corruption does not only happen in public sector but also in private sector because it is a deliberate action to provide fraud over particular amount on the financial report in order to decrease credibility of its report (Umar, 2012). Researchers whose work has focused on combatting corruption within NGOs have observed that prevalent forms of abuse of power (or, corruption) within this type of private sector organization include the establishment of "fictitious NGOs" solely for the purpose of generating income for the organization's executives or Board members, the receipt of kickback payments by NGO employees from prospective vendors with respect to the procurement of goods or services for the organization, and the solicitation of bribes by NGO employees from prospective beneficiaries who seek inclu-sion on NGO aid distribution lists (Sartor \& Beamish, 2018). After initial skepticism, companies worldwide are now adopting programs to combat corruption. A pioneer to combat corruption in private sector was was pioneered by U.S. companies in response to the scandals that led to the enactment of the 1977 Foreign Corrupt Practices Act. The U.S. Defense Industry Initiative pioneered refinements in the 1980s in the wake of serious irregularities in defense procurement (Arvis \& Berenbeim, 2003).
Survey data and interviews in East Asia, Europe, and North America confirm that business codes have become a worldwide phenomenon. A Conference Board survey conducted in 2000 that requested information from member companies about their anticorruption programs found such programs in private companies operating in 42 countries, including 7 in the East Asia and Pacific region.

\subsubsection{Legal approach}

Private offers particular actions to reduce corruption which consequenced by the Organisation for Economic Co-operation and Development (OECD) convention and it was ratified by its member. Similar with what was done by Britain combating the corruption, private put written law as prime component in their attempts. The written Law consist of two programs; sticks (prohibitions) and carrots (incentives). And both of programs have major developments are (a) the generalization of the extraterritoriality principle and (b) legal mitigation procedures based on company systems (Arvis \& Berenbeim, 2003).

The consciousness over corruption effect interfering fair competition, adoption of the convention and, even more, its enabling national laws galvanized the private sector in countries that had reputedly been cool to the compliance model. The French supports it industry rushed to implement huge ethics training courses, and Japanese and Korean corporations collectively moved to establish credible programs.

The credible program, as stated above, provides internal incentive which invloves managerial of the company. First, the company establish personal ethical commitment. Companies are more likely to cite "management leadership and personal convictions" than concern about external forces as a reason for making a serious anticorruption effort. By far the largest number of respondents to the 2000 Conference Board survey ranked "Senior management's leadership and personal convictions" as the most important factor in their companies' decision to develop anticorruption statements or programs (Arvis \& Berenbeim, 2003).

Secondly, managing reputational and operational risk which mostly on manager's minds. Most companies view fraud and corruption as risks, and there is an overwhelming perception that corrupt practices can have devastating effect to the company (Arvis \& Berenbeim, 2003).

\subsubsection{Compliance program}

After having written law either sticks and carrots, the next apporach is compliance program. Before 
industrial revolution, compliance program had been practiced by the companies both in east and west. Most companies take the view that an effective anticorruption effort is best achieved by institutionalizing a culture of compliance within the firm, backed up by systems designed to reduce the prospect of criminal activity within the company and detect such activity where it exists. However, the running of it does not always affected to the reduction of corruption.

Sumitomo - a multi-national corporation coming from Japan - , through its President sent message to all employees stating his vision for a global company "whose Corporate Vision, Management Principles, and Activity Guidelines reach across all the barriers of culture and language to be shared as common values by all employees across the globe, each of whom implements them with confidence and pride" in order to diseminate the company value to the employee.

In building such a culture of compliance, the challenge for international companies is to formulate core principles and implement credible procedures that will succeed in all the business cultures in which the firms operate. Companies also recognize that compliance systems and procedures themselves are most effective in environments of trust where employees feel free to ask questions and, if need be, report possible improprieties. Acommunity that is committed to a common set of purposes and values is one in which there is likely to be the highest level of trust.

There are four element influencing the effectivity of compliance program and make the anti-corruption succeed, as follows (Arvis \& Berenbeim, 2003):

a. The active engagement of company leadership; Arvin and Berembein in their survey stated that the active involvement of the leader in the company either management or board brouhgt significant progress in the company.

b. A Code of company values and employee conduct, which in turn shapes a set of detailed and consistent statements of policies and operating procedures.

A values statement or code of conduct is the foundation for a company anticorruption program. Such a statement provides general guidance for decisionmaking that is in accord with the company's values and beliefs. Increasingly, large companies, particularly those that do business outside their home countries, have adopted values statements regardless of the firm's country or culture of origin.

c. A delivery mechanism to ensure that all employees are familiar with the company's code and ethics expectations.
There are trends over the companies now distribute their anticorruption statements to jointventure partners, governments, vendors, and suppliers. Beside that, companies actively send disclosure statement signed by its employee. Then, after distribut their anticorruption statement, they establish discussion and training that can be a strengthen way to their understanding of their commitment.

d. Warning systems that apply to the supervision and commitment of resources and reporting, and whistle-blowing arrangements.

Hotlines. Of the typical components of ethics systems, warning systems or hotlines attract the most stubborn cultural resistance when they are introduced. But research and company experience affirm that successful warning systems are at work in most regions and industries and that vague generalizations about the unwillingness of people in certain cultures to use these systems because they might be regarded as "informers" are vastly overstated. But, there is other action beside hotline. To identify corruption risk factors, one of the companies surveyed for this study divided its bidding process into three phases of review and analysis of cost margins which some senior executives interviewed say that the best way to control unauthorized payments is to keep extremely tight project and service budgets.
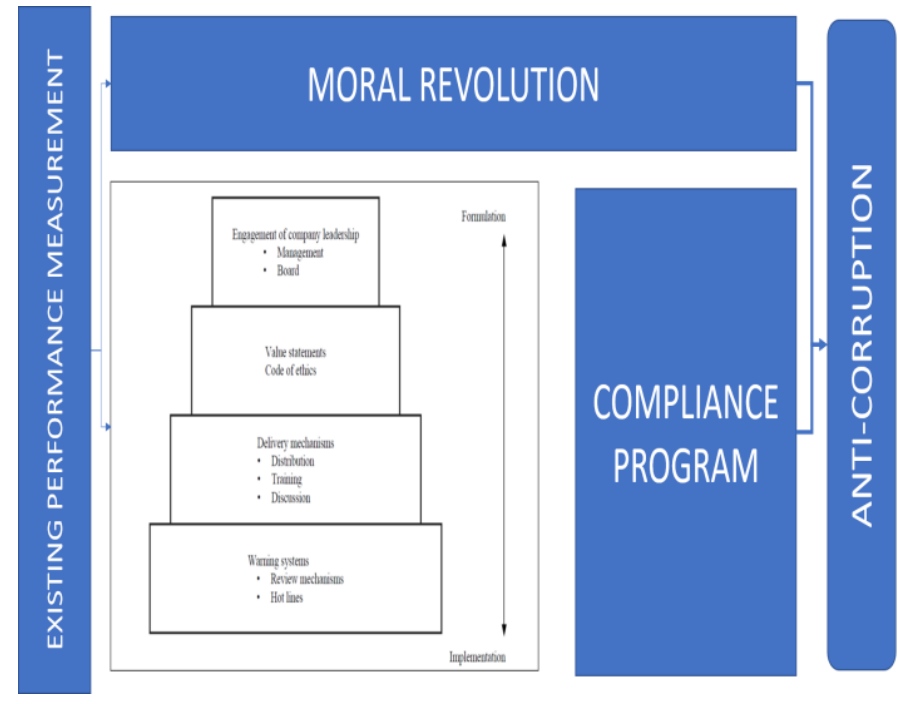

Thus, the experiences that happen in Britain and the private sector have similar pattern. They placed the anticorruption statement on written law though uncertain variable did not clear yet. However, we can emphasize the "moral evalotion" believed in Britain could be a variable to reduce corruption in civil servants. Not only that, compliance program which is effectively believed able to combain between civil servants and its leader 
because it involves both of them should be other variable of anti-corruption of performance measurement.

\section{Conclusion}

Peformance measurement on civil servant, nowadays, does not optimally reduce the number of corruption because it does not place variable of anticorruption on measuring the civil servant' measurement. Gaining from Britain and private sector, it should be involved moral revolution and compliance program, which not only depend on the employee but also the manager as the leader.

\section{References}

Arvis, J.-F., \& Berenbeim, R. E. (2003). Fighting Corruption in East Asia: Solution from the Private Sector. Washington: The Wold Bank.

Asian Development Bank. (2015). Governance in Developing Asia Public Service Delivery and Empowerment. Massachusetts: Edward Elgar Publishing Limited.

Badan Kepegawaian Negara. (2018, September 4). $B K N$. Retrieved from http://www.bkn.go.id/wpcontent/uploads/2018/09/Pertajam-Penyikapanatas-PNS-Tipikor.pdf

Bourne, M., Neely, A., Mills, J., \& Platts, K. ( 2003). Implementing performance measurement systems: a literature review. International Journal of Business Performance Management, 3.

Girling, J. (1997). Corruption, Capitalism, and Democracy. London: Routledge.

Nawaz, F., \& Bridi, A. (2008). Overview of Corruption and Anti-Corruption in the Philippines. U4 Expert Answer , 4.

Paul, E. Motivating Civil Servants for Reform and Performance. New York, USA: United Nations Development Programme.

Pratama, A. N. (2019, March 21). Kompas. Retrieved from https://internasional.kompas.com/read/2019/03/ 21/13215951/mengenal-lembaga-anti-korupsiseperti-kpk-di-8-negara?page=all

Sartor, M. A., \& Beamish, P. W. (2018). Private Sector Corruption, Public Sector Corruption and the Organizational Structure of Foreign Subsidiaries. Journal of Business Ethics.

Transparency International. (2018). What is Corruption. Retrieved from Transparency International: https://www.transparency.org/what-iscorruption\#define

Umar, H. (2012). Pengawasan utuk Pemberantasan Korupsi. Jurnal Akuntansi dan Auditing , 112. 